\title{
RELATIONSHIP BETWEEN LEARNING DISCIPLINE, PEER FRIENDS AND ATTENTION OF OLD PEOPLE WITH MATHEMATICS STUDENT LEARNING OUTCOMES IN SMA NEGERI 3 BANTUL
}

\author{
Sefrilina Hastutiningsih ${ }^{a}$, Sunaryo ${ }^{b}$ \\ Program Studi Pendidikan Matematika Universitas Ahmad Dahlan \\ Jalan Ring Road Selatan, Tamanan, Banguntapan, Bantul Yogyakarta \\ asefri.linaa@gmail.com, ${ }^{\text {b sunaryo.bener@yahoo.co.id }}$
}

\begin{abstract}
A minimum outcome is related to many factors. The discipline of learning, peers, and parent's attention are some of the factors that were related to learning outcomes. This study aims to determine the presence or absence of a positive and significant relationship between the disciplines of learning, peers and parents' attention to learnings outcomes math class X Semester SMA Negeri 3 Bantul academic year 2015/2016. The population of this the research second-semester students of class X SMA Negeri 3 Bantul Academic Year 2015/2016 consists of 7 classes. The research sample by random sampling technique then got X 6 as the sample of the research and X 5 as a trial class. The techniques of data collection was conducted by questionnaire and test methods. Test instruments used validity, reliability test and test different power. The prerequisite analysis test including normality test, linearity test, and the independence test. The data are collected the researcher uses product-moment and multiple linear regression analysis to analyze the data. The results of the data shows that there is a positive and significant correlation between learning discipline, peers and parents attention to the results of learning mathematics, with $F_{\text {stat }}=6,2987$ and $F_{\text {table }}=3,03$, in order to, obtain $F_{\text {count }}>F_{\text {table }}$. The coefficients multiple correlation (R) of 0,6716 with a linear regression equation $\hat{Y}=-115,1360+0,8845$ $X_{1}+0,8508 X_{2}+0,2196 X_{3}$. The contribution large relative $\left(X_{1}\right)=53.0585 \%,\left(X_{2}\right)=31.8447 \%,\left(X_{3}\right)=$ $15.0968 \%$ with double the coefficient of determination of $\left(R^{2}\right)$ of 0.510 as well as the effective contribution $\left(\mathrm{X}_{1}\right)=23,9307 \%,\left(\mathrm{X}_{2}\right)=14.3627 \%,\left(\mathrm{X}_{3}\right)=6.8090 \%$.
\end{abstract}

Keywords: Disciplinary Learning, Peer, Parents Attention, Outcomes Mathematics Learning.

\section{INTRODUCTION}

Education is a human effort to broaden the horizons of knowledge in order to shape values, attitudes, and behavior. Almost everyone is subject to education and education. Because education is never separate from human life. Children receive education from their parents and later when they are adults and have a family they will also educate their children. The education sector is one of the national development targets which continuously undergoes updates that are adjusted to the situation and conditions that existed at that time. Renewal of education is carried out as an effort to meet the demands of the development of science and technology, the arts, and the development of society. Mathematics is a field of study that is studied by all students from elementary school to high school and even in college. Mathematics has an important role in everyday life, indirectly human activities require concepts and mathematical calculations. Learning success is basically caused by many factors. According to Slameto (2010: 54-72), "Factors that affect learning are many types but can be classified into two groups only, namely internal factors and external factors.

Internal factors are factors that exist in the individual who is studying, namely scientific factors, psychological factors, and fatigue factors. While external factors are factors that exist outside the individual, namely family factors, school factors, and community factors ". One internal factor is learning discipline. Discipline arises from within the soul, students who have high discipline will have a large responsibility for learning. Nawawi, Hadari (1985: 128) said that "discipline is an effort to instill awareness of each person about their duties and responsibilities in order to become people who are willing and able to assume responsibility for all their work."

One of the external factors that influence the learning outcomes of mathematics is peers. Peers are friends who have the most influence on children's development. When children have been in school, 
their peers are classmates and playgroups. Children learn to give and receive in associating with their peers. Peers have a function like that said Santrock, John (2007: 205) "one of the most important functions of the peerage is to provide sources of information and comparisons about the world outside the family. Children receive feedback about their abilities from their peer group. "The role of parents as the first educator for the development of a child's personality in learning outcomes is very large. Parents must monitor the child's learning process well. Support from parents is also needed by children because most of the time students are more at home. Parental attention is very important for a child. According to Ahmadi, Abu (2004: 92) "Parents who are always authoritarian, that is imposing their will on their children, then children will develop into passive humans, do not take initiative, lack confidence in themselves, are hesitant, fear and so on. But if the parents in the family act in democracy, then it will result in the development of their children, they will become children who are full of initiative, active and diligent, not afraid, not hesitant about their goals, always optimistic, have a sense of responsibility and believe in yourself. So that children are not passive so parents are obliged to educate well without any coercion. "

The problems in this study are: 1) Is there a positive and significant relationship between learning discipline with the mathematics learning outcomes of class X students in the even semester of SMA Negeri 3 Bantul 2015/2016 academic year? 2) Is there a positive and significant relationship between peers with learning outcomes mathematics of class $X$ students in even semester of SMA Negeri 3 Bantul in the 2015/2016 academic year ?, 3) Is there a positive and significant relationship between parents' attention to mathematics learning outcomes of class X students in even semester SMA 3 Bantul in the academic year 2015/2016? a positive and significant relationship between the discipline of learning and peers with the mathematics learning outcomes of class X students in the even semester of SMA Negeri 3 Bantul in the 2015/2016 academic year? 5) Is there a positive and significant relationship between learning discipline and parents 'attention to the students' mathematics learning outcomes $\mathrm{X}$ even semester 3 SMA Negeri Bantul in the 2015/2016 academic year ?, 6) Is there a positive and significant relationship between a between peers and parents' attention to the mathematics learning outcomes of class X students in the even semester of SMA Negeri 3 Bantul in the 2015/2016 academic year? 7) Is there a positive and significant relationship between the discipline of learning, peers and parents' attention to students' mathematics learning outcomes class X even semester of SMA Negeri 3 Bantul in the 2015/2016 academic year?

The objectives of this study are: 1) To find out whether there is a positive or significant relationship between learning discipline and the mathematics learning outcomes of class X students in the even semester of SMA Negeri 3 Bantul in the 2015/2016 academic year, 2) Knowing whether there is a positive or significant relationship between peers with the mathematics learning outcomes of class X students in even semester SMA Negeri 3 Bantul in the 2015/2016 academic year, 3) Knowing whether or not there is a positive and significant relationship between parental attention and the results of mathematics learning in class X even semester of SMA Negeri 3 Bantul in the 2015/2016 academic year, 4) Knowing whether or not there is a positive and significant relationship between discipline of learning and peers with the mathematics learning outcomes of class $X$ students in even semester SMA Negeri 3 Bantul in the 2015/2016 academic year, 5) Knowing whether there is a positive or significant relationship between the discipline of learning and the attention of parents with the results of mathematics learning in class X students even semester SMA Negeri 3 Bantul in the 2015/2016 academic year, 6) Knowing whether or not there is a positive and significant relationship between peers and the attention of parents with mathematics learning outcomes of class $\mathrm{X}$ students in even semester SMA Negeri 3 Bantul in the 2015/2016 academic year, 7) Knowing whether or not there is a positive and significant relationship between the discipline of learning, peers and the attention of parents with the mathematics learning outcomes of class X students in the even semester of SMA 3 Bantul in the 2015/2016 academic year. 


\section{METHODS}

This research is classified as quantitative by taking place in SMA Negeri 3 Bantul in the odd semester of the 2015/2016 academic year. The population in this study were all students of class X even semester SMA Negeri 3 Bantul which consisted of 7 classes namely X 1, X 2, X 3, X 4, X 5, X 6, and X 7 which amounted to 189 students. As a sample class taken class X 6 as many as 27 students using a random sampling technique. In this study, the data collection methods used were questionnaires and test methods. The questionnaire method to obtain data on learning discipline, peers and parents' attention while the test method is to obtain data on student learning outcomes.

The test used is the analysis prerequisite test by the normality test of the Chi-square formula, the linearity test of the F-test formula and the test of the independence of the Chi-square formula. The research hypothesis test uses a simple correlation test, multiple regression analysis and multiple linear regression tests with three independent variables. The research hypothesis test uses a simple correlation test to determine whether or not there is a positive and significant relationship between 1) learning disciplines with students 'mathematics learnings outcomes, 2) peers with students' mathematics learning outcomes and 3) parents 'attention to students' mathematics learning outcomes. Furthermore, the research hypothesis test using a multiple regression analysis test was conducted to determine whether or not there is a positive and significant relationship between 1) the discipline of learning and peers with student mathematics learning outcomes, 2) discipline of learning and the attention of parents with the results of student mathematics learning, 3) Peers friends and parents 'attention to students' mathematics learning outcomes. While the multiple linear regression test with three independent variables was conducted to determine whether there was a positive and significant relationship between the discipline of learning, peers and parents 'attention to the students' mathematics learning outcomes.

\section{RESULTS AND DISCUSSION}

The summary results of the normal ability normality test can be seen in Table 1 .

Table 1. Summary of Normality Test Results

\begin{tabular}{|l|c|c|c|}
\hline \multicolumn{1}{|c|}{ Variable } & $\boldsymbol{X}_{\text {count }}^{\mathbf{2}}$ & $\boldsymbol{X}_{\text {table }}^{\mathbf{2}}$ & $\mathbf{d f}$ \\
\hline Learning discipline & 2,7478 & 5,9915 & 2 \\
\hline Friends of the same age & 2,2699 & 5,9915 & 2 \\
\hline Parents attention & 6,4069 & 7,8147 & 3 \\
\hline $\begin{array}{l}\text { Mathematics learning } \\
\text { outcomes }\end{array}$ & 4,2563 & 5,9915 & 2 \\
\hline
\end{tabular}

From the normality test at a significant level, 5 is seen $X_{\text {count }}^{2} \leq X_{\text {table }}^{2}$, this means that the distribution of data obtained in each variable is normally distributed.

The summary of linearity test results can be seen in Table 2 .

Table 2. Summary of Linearity Test Results

\begin{tabular}{|c|c|c|}
\hline Variable & $\mathbf{F}_{\text {count }}$ & $\boldsymbol{F}_{\text {table }}$ \\
\hline $\mathrm{X}_{1}$ with $\mathrm{Y}$ & 0,7961 & 2,85 \\
\hline $\mathrm{X}_{2}$ with $\mathrm{Y}$ & 0,3497 & 2,99 \\
\hline $\mathrm{X}_{3}$ with $\mathrm{Y}$ & $-0,2580$ & 3,19 \\
\hline
\end{tabular}

From the linearity test at a significant level of $5 \%(\alpha=0,05)$ and the degree of freedom $v_{1}$ numerator $k-2$ and $\mathrm{v}_{2}$ denominator $\mathrm{n}-\mathrm{k}$ seen $F_{\text {count }} \leq F_{\text {table }(1-\alpha)(k-2, N-k)}$, this means that there is a linear relationship between the independent variable $(\mathrm{X})$ and the dependent variable $(\mathrm{Y})$.

The summary of the results of independent tests can be seen in Table 3 . 
Table 3. Summary of Independence Test Results

\begin{tabular}{|c|c|c|c|}
\hline Variable & $\boldsymbol{X}_{\text {count }}^{\mathbf{2}}$ & $\boldsymbol{X}_{\text {table }}^{\mathbf{2}}$, & Df \\
\hline $\mathrm{X}_{1}$ with $\mathrm{X}_{2}$ & 32,006 & 37,6525 & 25 \\
\hline $\mathrm{X}_{1}$ with $\mathrm{X}_{3}$ & 33,105 & 37,6525 & 25 \\
\hline $\mathrm{X}_{2}$ with $\mathrm{X}_{3}$ & 30,486 & 37,6525 & 25 \\
\hline
\end{tabular}

From independent testing at a significant level of 5\% $(\alpha=0,05)$ and the degree of freedom $(d k)=(k-1)(b-1)$ seen $X_{\text {count }}^{2} \leq X_{\text {table }}^{2}$, this means that the distribution of data obtained on each variable is independent.

In the first hypothesis test obtained a simple correlation coefficient $r$ of 0.5116 at a significant level of $5 \%$. So that the $\mathrm{r}^{2}$ determinant coefficient obtained is equal to 0,2617 which can be explained that $26.17 \%$ of learning outcomes are influenced by learning discipline while the rest is influenced by other factors. The variation in mathematics learning outcomes $(\mathrm{Y})$ is explained by learning discipline $\left(\mathrm{X}_{1}\right)$ through linear lines $\widehat{\mathrm{Y}}=-21,1482+0,9673 \mathrm{X}_{1}$.

In the second hypothesis test, the correlation coefficient (r) 0.3708 was obtained at a significant level of $5 \%$. So that the determinant coefficient $\left(\mathrm{r}^{2}\right)$ is 0.1375 which can explain $13.75 \%$ of learning outcomes influenced by peers while the rest is influenced by other factors. There are variations in mathematics learning outcomes $(\mathrm{Y})$ explained by peers $\left(\mathrm{X}_{2}\right)$ through linear lines $\hat{\mathrm{Y}}=-9,7784+$ $0,8144 X_{2}$.

In the third hypothesis test, the correlation coefficient (r) is 0.3622 . So that it is obtained $\left(\mathrm{r}^{2}\right)$ of 0.1311 which can explain $13.11 \%$ of learning outcomes influenced by the attention of parents while the rest is influenced by other factors. There are variations in mathematics learning outcomes (Y) explained by peers $\left(\mathrm{X}_{3}\right)$ through linear lines $\hat{\mathrm{Y}}=29,6613+0,4230 \mathrm{X}_{3}$.

From the multiple correlation analysis, the fourth hypothesis test obtained the value of multiple correlation coefficient ( $r$ ) of 0.6480 . In this study also obtained the coefficient of determination $\left(\mathrm{r}^{2}\right)$ of 0.4199 means that $41.99 \%$ of learning outcomes are influenced by the discipline of learning and peers while the rest is influenced by other factors. The variation in mathematics learning outcomes $(\mathrm{Y})$ can be explained by the discipline of learning $\left(\mathrm{X}_{1}\right)$ and peers friend $\left(\mathrm{X}_{2}\right)$ through linear lines $\hat{\mathrm{Y}}=$ $-108,6038+1,0061 X_{1}+0,8746 X_{2}$. Whereas for relative donations $X_{1}$ is equal to $64,8342 \%$ and $X_{2}$ of $35.1658 \%$ and effective contribution of $X_{1}$ of $27.2215 \%$ and $X_{2}$ of $14.7648 \%$.

From the multiple correlation analysis, the fifth hypothesis test obtained the value of multiple correlation coefficients of 0.5495 . In this study also obtained the coefficient of determination $\left(R^{2}\right)$ of 0.3019 means that $30.19 \%$ of learning outcomes are influenced by the discipline of learning and the attention of parents while the rest is influenced by other factors. There are variations in mathematics learning outcomes that can be explained by learning discipline $\left(\mathrm{X}_{1}\right)$ and parental attention $\left(\mathrm{X}_{3}\right)$ through linear lines $\hat{\mathrm{Y}}=-31,2577+0,8306 \mathrm{X}_{1}+0,2490 \mathrm{X}_{3}$. Whereas the relative contribution of $\mathrm{X} 1$ is $74.4292 \%$ and $X_{3}$ is $25.5708 \%$ and the effective contribution of $X_{1}$ is $22.4729 \%$ and $X_{3}$ is $7.7208 \%$.

From the multiple correlation analysis of the sixth hypothesis test, the multiple correlation coefficient $(\mathrm{R})$ is 0.5082 . In this study the coefficient of determination $\left(\mathrm{R}^{2}\right)$ of 0.2583 means that $25.83 \%$ of learning outcomes are influenced by peers and parents' attention while the rest is influenced by other factors. There are variations in mathematics learning outcomes $(\mathrm{Y})$ that can be explained by peers $\left(\mathrm{X}_{2}\right)$ and parents' attention $\left(\mathrm{X}_{3}\right)$ through linear lines $\hat{\mathrm{Y}}-43,9669+0,7838 \mathrm{X}_{2}+0,4063 \mathrm{X}_{3}$. Whereas the relative contribution of $\mathrm{X}_{2}$ is $51.2255 \%$ and $\mathrm{X} 3$ is $48.7745 \%$ and the effective contribution of $\mathrm{X}_{2}$ is $13.2310 \%$ and $\mathrm{X}_{3}$ is $12.5980 \%$.

From the multiple correlation analysis, the seventh hypothesis test obtained the multiple correlation coefficient $(R)$ of 0.6716 . This study also obtained the coefficient of determination $\left(R^{2}\right)$ of 0.4510 means that $45.10 \%$ is influenced by parenting discipline of learning, peers and the attention of parents while the rest by other factors. Variations in mathematics learning outcomes can be explained by learning discipline $\left(\mathrm{X}_{1}\right)$, peers $\left(\mathrm{X}_{2}\right)$, and parental attention $\left(\mathrm{X}_{3}\right)$ through linear lines $\hat{\mathrm{Y}}$ 
$=-115,1360+0,8845 X_{1}+0,8508 X_{2}+0,2196 X_{3}$ While the relative contribution of $X_{1}$ is $530585 \%, X_{2}$ is $31.8447 \%$ and $X_{3}$ is $15.0968 \%$ and the effective contribution of $X_{1}$ is $23.9307 \%, X_{2}$ is $14.3627 \%$ and $\mathrm{X}_{3}$ is $6.8090 \%$.

\section{CONCLUSION}

1. There is a positive and significant relationship between the discipline of learning and the mathematics learning outcomes of class X students in the even semester of SMA Negeri 3 Bantul in the 2015/2016 academic year. Simple correlation coefficient (r) between disciplines of learning with mathematics learning outcomes of 0.5116 . As well as a simple regression equation $\mathrm{Y}$ over $\mathrm{X}_{1}$ is $\hat{Y}=-21,1482+0,9673 \mathrm{X}_{1}$.

2. There is a positive and significant relationship between peers with the mathematics learning outcomes of class X students in even semester SMA Negeri 3 Bantul 2015/2016 academic year. Simple correlation coefficient $(r)$ between peers with math learning outcomes of 0.3708 . In addition, also obtained a simple regression equation $\mathrm{Y}$ over $\mathrm{X}_{2}$ is $\hat{Y}=-9,7784+0,8144 \mathrm{X}_{2}$

3. 3. There is a positive and significant relationship between the attentions of parents with the mathematics learning outcomes of class X students in the even semester of SMA Negeri 3 Bantul in the 2015/2016 school year. The simple correlation coefficient (r) between parents' attention and mathematics learning outcomes is 0.3622 . In addition, also obtained a simple regression equation $\mathrm{Y}$ on $\mathrm{X}_{3}$ is $\widehat{\mathrm{Y}}=29,6613+0,4230 \mathrm{X}_{3}$.

4. There is a positive and significant relationship between the discipline of learning and peers with the mathematics learning outcomes of class X students in even semester SMA Negeri 3 Bantul 2015/2016 academic year. Multiple correlation coefficient (R) between the discipline of learning and peers with mathematics learning outcomes of 0.6480 and coefficient of determination $\left(R^{2}\right)$ of 0.4199 with linear line equations $\quad \widehat{Y}=-108,6038+1,0061 \mathrm{X}_{1}+0,8746 \mathrm{X}_{2}$.

5. There is a positive and significant relationship between the discipline of learning and the attention of parents with the mathematics learning outcomes of class $\mathrm{X}$ students in even semester SMA Negeri 3 Bantul 2015/2016 academic year. Correlation coefficient (R) between learning discipline and attention of parents with mathematics learning outcomes of 0.5495 and the coefficient of determination $\left(R^{2}\right)$ is 0.3019 with linear line equations $\widehat{Y}=-31,2577+0,8306 \mathrm{X}_{1}+$ $0,2490 \mathrm{X}_{3}$.

6. There is a positive and significant relationship between peers and parents' attention to the mathematics learning outcomes of class $X$ students in even semester SMA Negeri 3 Bantul 2015/2016 academic year. Correlation coefficient (R) between peers and the attention of parents with mathematical learning outcomes of 0.5082 and coefficient of determination $\left(\mathrm{R}^{2}\right)$ of 0.2583 with linear line equations $\widehat{Y}=-43,9669+0,7838 X_{2}+0,4063 X_{3}$.

7. There is a positive and significant relationship between the discipline of learning, peers and the attention of parents with the mathematics learning outcomes of class $\mathrm{X}$ students in the even semester of SMA Negeri 3 Bantul 2015/2016 academic year. Correlation coefficient (R) between learning discipline, peers and attention parents with mathematical learning outcomes of 0.6716 and a coefficient of determination $\left(\mathrm{R}^{2}\right)$ of 0.4510 with linear line equations $\hat{Y}=-115,1360+$ $0,8845 X_{1}+0,8508 X_{2}+0,2196 X_{3}$.

\section{REFERENCES}

Ahmadi, Abu. 2004. Sosiologi Pendidikan. Jakarta: Rineka Cipta.

Nawawi, Hadari. 1985. Administrasi Pendidikan. Jakarta: Gunung Agung.

Santrock, John. 2003. Adolescence Perkembangan Remaja. Jakarta: Erlangga.

Slameto. 2010. Belajar Dan Faktor-Faktor Yang Mempengaruhinya. Jakarta: Rineka Cipta. 